удК 342.951:351

DOI https://doi.org/10.32837/apdp.v0i89.3185

B. B. $3 y \check{u}$

\title{
СПІВВІДНОШЕННЯ ПОНЯТЬ «ЗАХИСТ І ОХОРОНА СУБ’СКТИВНИХ ПУБЛІЧНИХ ПРАВ» ТА «ВІДПОВІДАЛЬНІСТЬ ЗА ПОРУШЕННЯ СУБ'СКТИВНОГО ПУБЛІЧНОГО ПРАВА»
}

Постановка проблеми. Розвиток України як правової держави повинен відбуватись одночасно з удосконаленням організаційно-правового механізму охорони й захисту прав і свобод людини та громадянина. Необхідний елемент цього механізму - адміністративний порядок оскарження та ефективна судова система, здатна задовольнити стандарти верховенства права у сфері захисту прав людини у публічних правовідносинах, що забезпечує можливість оскарження в суді рішень, дій чи бездіяльності суб'єктів владних повноважень. Необхідно звернути увагу, що гарантоване ст. 55 Конституції України право на захист можливе лише в разі його порушення, тому логічною вимогою в захисті такого права є обгрунтування порушення. Порушення також має бути реальним, стосуватися індивідуально вираженого права особи, тобто конкретизоване в законах України. Натомість захист порушеного права повинен бути ефективним [1]. Так, Європейський суд з прав людини у своїх рішеннях неодноразово підкреслював необхідність ефективного захисту прав заявників. Наприклад, у п. 75 рішення від 05.04.2005 у справі «Афанасьєв проти України» (заява № 38722/02) ЄСПЛ зазначає, що засіб захисту, який вимагається згаданою статтею, повинен бути «ефективним», як у законі, так і на практиці, зокрема, в тому сенсі, щоб його використання не було ускладнене діями або недоглядом органів влади відповідної держави [2].

Аналіз останніх досліджень і публікацій. Не дивлячись на актуальність зазначеної проблеми, у юридичній науці співвідношення понять «захист і охорона суб’єктивних публічних прав» та «відповідальність за порушення суб'єктивного публічного права» учасників адміністративних відносин приділяється недостатньо уваги. Так, уваги потребують праці Т.С. Кисельової, Г.В. Срьоменко, Є.Р. Бершеди, С.Ф. Демченка, В.В. Рєзнікової, А.П. Гаврилішина, В.В. Землянської, Н. Мазаракі та інших. Ці роботи складають наукову базу для подальшого дослідження зазначеної проблеми і фактично започатковують наукову дискусію щодо перспектив їх законодавчого удосконалення.

Метою статті є аналіз співвідношення понять «захист і охорона суб’ єктивних публічних прав» та «відповідальність за порушення суб'єктивного публічного права».

Виклад основного матеріалу дослідження. Як зазначено вище, право на захист реалізується у кожному випадку лише в разі його порушення, тобто виникнення правового спору за участю органів публічної адміністрації, де необхідно з'ясовувати, чи реалізовував вказаний орган владні управлінські функції у правовідносинах, що передували виникненню спору. Також треба підкреслити, що владні

(c) В. В. Зуй, 2021 
управлінські функції орган публічної адміністрації повинен виконувати саме в тих правовідносинах, у яких виник спір [3, с. 5]. Слід зазначити, що в науці адміністративного права під захистом зазвичай розуміють адміністративно-процесуальну функцію як одну з напрямків процесуальної діяльності, що складається із дій учасників адміністративного процесу [4, с. 31].

Звернемо увагу на історичний аспект. Зокрема, в українській історії спори також мають свою історію. Зокрема, О. Миколенко говорив про те, що важливо розрізняти поняття «правовий спір» та «правопорушення», адже кожне із цих понять має свій специфічний зміст. Правовий спір завжди є результатом наявності юридичних колізій у правовій системі держави і виникає між суб'єктами права у зв'язку з порушенням суб'єктивних прав фізичних або юридичних осіб. Правопорушення також можна інколи розглядати як результат наявності в системі держави правових колізій. Однак кожне правопорушення - це порушення встановленої законодавством заборони, що не властиве правовому спору, бо в разі правового спору порушуються не правові заборони, а суб'єктивні права особи. До того ж, як правило, правопорушення в чинному законодавстві України представлене у вигляді юридичної конструкції - складу правопорушення, що характеризується наявністю чотирьох елементів: суб'єкта і суб'єктивної сторони правопорушення, об'єкта і об'єктивної сторони правопорушення. Критеріями відмежування публічно-правового спору від інших правових спорів є його суб'єктний склад та характер правовідносин, з яких він виникає. У свою чергу, участь у відносинах органу з державно-владними повноваженнями наділяє ці відносини публічно-правовим характером. Сам же спір, що виникає з таких відносин, набуває ознак публічно-правового [5, с. 31].

Так, можна сказати, що в кожному випадку виникнення правового спору за участі органів публічної адміністрації громадяни вступають із органами виконавчої влади в адміністративно-правові відносини. Адміністративні правовідносини - це суспільні відносини, що виникають у сфері державного управління та врегульовані нормами адміністративного права. Оскільки адміністративні правовідносини є різновидом правовідносин, їм притаманні загальні риси останніх, зокрема: вони є вольовими суспільними відносинами, тобто право, що регулює їх, спрямовує їх поведінку у відповідності з інтересами суспільства; вони є суспільними відносинами, врегульованими нормами права. Без права та його норм не було б правовідносин; учасники правовідносин наділені суб'єктивними правами і несуть юридичні обов'язки. I перші, і другі виникають відповідно до вимог норм права, що визначають коло суб'єктивних прав і обов'язків; правовідносини - це спосіб конкретизації норм права, оскільки саме в ньому права та обов'язки завжди прив'язані до певної ситуації, конкретні і належать певним суб'єктам; правовідносини - це такі відносини, реалізація яких забезпечується можливістю застосування адміністративного примусу [6, с. 31]. Звернемо увагу, що суб'єктивні публічні права приватних осіб можна визначити як права, що використовуються громадянами у сфері державного управління, регулюють відносини приватних осіб із державою, є складовим елементом їх адміністративно-правового статусу і реалізуються під час відносин з органами виконавчої влади. 
Щодо правової основи захисту суб’єктивних публічних прав приватних осіб, то можна сказати що остання базується на положеннях ст. 3 Конституції України, відповідно до якої людина, її життя і здоров'я, честь і гідність, недоторканність і безпека визнаються в Україні найвищою соціальною цінністю, а утвердження й забезпечення прав людини є головним обов'язком держави. Також ст. 40 Конституції України визначено право людини й громадянина направляти індивідуальні чи колективні письмові звернення або особисто звертатися до органів державної влади, органів місцевого самоврядування та посадових і службових осіб цих органів, що зобов' язані розглянути звернення й дати обгрунтовану відповідь у встановлений законом строк. Окрім того, відповідно до частини другої ст. 55 Конституції України кожному гарантується захист своїх прав, свобод та інтересів від порушень і протиправних посягань будь-якими не забороненими законом засобами.

Щодо системи суб'єктивних публічних прав приватних осіб, то зазначена система складається: із прав на свободу слова, зібрань, об’єднання, віросповідання; із прав, пов'язаних з участю громадян в управлінні державними справами (активне та пасивне виборче право, право на здійснення громадського контролю, право на участь у відправленні правосуддя); із прав на отримання адміністративних послуг; із прав на користування публічним майном (вулиці, площі, парки тощо); із прав, пов'язаних із можливістю захисту своїх прав і свобод (право на звернення)» [6].

Існують різні класифікації поділу суб’єктивних публічних прав. В.К. Колпаков зазначає: «В адміністративно-правовій науці прийнято виділяти три групи прав громадян: а) соціально-економічні, які стосуються основ життя людей: право на працю, матеріальне забезпечення, право на освіту, на охорону здоров'я. Вони становлять основу правового становища громадян; б) політичні права і свободи: права на свободу думки, совісті, релігії, зібрань, мітингів, демонстрацій, об'єднання в політичні партії; право вносити пропозиції до державних органів і критикувати недоліки, оскаржувати в суді дії посадових осіб; право на судовий захист. Сюди також належать право обиратися й бути обраним у ради будь-якого рівня; право на користування досягненнями культури, свободу наукової, технічної, художньої творчості; в) особисті права і свободи - це права, які пов'язані з виконанням громадянами дій, спрямованих на задоволення особистих потреб» [7, с. 159].

На думку Ю.П. Битяка, за своїм змістом права громадян поділяються на: 1) участь у державному управління та соціально-політичну активність: право на державну службу, внесення пропозицій, одержання необхідної інформації та документів у встановленій формі, проведення зборів, мітингів, демонстрацій, створення громадських об'єднань чи входження в них тощо; 2) одержання допомоги від відповідних компетентних організацій: право на медичну, санітарноепідеміологічну допомогу, безкоштовне користування благами (бібліотеками, парками тощо), користування транспортом одержання платних та інших послуг; 3) права, що захищаються: в адміністративному порядку (адміністративна скарга, адміністративно-юрисдикційне провадження), у судовому порядку (скарга, позов), особисто громадянином (необхідна оборона)» [8, с. 50].

B.М. Манохін виділяє таку класифікацію: 1) права громадян, що регулюються нормами адміністративного права. До складу цієї групи належить право громадян 
на участь у державному управлінні, що створює основу його адміністративно-правового статусу; 2) права громадян, які регулюються нормами адміністративного та інших галузей права. До цієї групи прав належать права та свободи, що пов'язані з реалізацією соціально-економічних, політичних, особистих та культурних прав і свобод громадян (право на працю, на відпочинок, на користування суспільними благами тощо). За фактичної реалізаціїцієї групи прав та свобод громадянин вступає у відносини з «управлінським апаратом» підприємств, установ, організацій» [9, с. 182].

До уваги треба взяти і класифікацію Д.М. Бахраха: «За системою реалізації виділяють права абсолютні (безумовні) й відносні. До абсолютних належать права, якими особа користується на свій розсуд (наприклад, право на адміністративну скаргу, вибір імені, працевлаштування, здобуття загальної середньої освіти). Реалізація абсолютних прав залежить від волі громадянина. Відносними є права, для реалізації яких потрібен акт державного органу (наприклад, наказ про призначення на посаду, ліцензія на здійснення певної діяльності» [10].

Варто зазначити, що суб'єктивні публічні права захищають не тільки сферу особистих інтересів, а й сферу публічних інтересів (наприклад, захист інтересів держави від незаконних дій платників податків). Таким чином, можна зробити висновок, що суб'єктивні публічні права спрямовані, з одного боку, на посилення соціальної ролі держави, а з іншого - обмежують публічну владу, забезпечуючи особисті інтереси громадян у публічній сфері.

Додамо, що у правовій державі відповідальність за протиправну поведінку мають нести рівною мірою як фізичні та юридичні особи, так і держава, її органи, органи місцевого самоврядування, їхні службові та посадові особи в порядку, передбаченому законодавством. Що стосується відповідальності, то адміністративному праву належить важлива роль у захисті особи від неправомірних дій суб'єктів влади, адже саме у взаємовідносинах із цими суб'єктами найбільш конкретно виявляється адміністративно-правовий статус громадян. Крім того, посадові особи можуть свідомо порушувати права громадян, зловживаючи довіреною їм владою.

Так, у випадках прийняття незаконних рішень, незаконних дій чи бездіяльності органів державної влади, органів місцевого самоврядування, їхніх посадових і службових осіб кожній особі надається право на захист. Слід зазначити, що відповідно до Закону України «Про звернення громадян», а саме статті 24, відповідальність посадових осіб за порушення законодавства про звернення громадян полягає у тому, що особи, винні в порушенні зазначеного закону, несуть цивільну, адміністративну або кримінальну відповідальність, передбачену законодавством України. А стаття 25 передбачає відшкодування збитків громадянину у зв'язку з порушенням вимог Закону України «Про звернення громадян» під час розгляду його скарги. У разі задоволення скарги орган або посадова особа, які прийняли неправомірне рішення щодо звернення громадянина, відшкодовують йому завдані матеріальні збитки, пов'язані з поданням і розглядом скарги, обгрунтовані витрати, понесені у зв'язку з виїздом для розгляду скарги на вимогу відповідного органу, і втрачений за цей час заробіток. Спори про стягнення витрат розглядаються в судовому порядку. Громадянину на його вимогу і в порядку, встановленому чинним законодавством, можуть бути відшкодовані моральні збитки, завдані 
неправомірними діями або рішеннями органу чи посадової особи під час розгляду скарги. Розмір відшкодування моральних (немайнових) збитків у грошовому виразі визначається судом [11].

Висновки. Здійснений аналіз дає підстави для висновку про те, що поняття «охорона» $\mathrm{i}$ «захист» $\mathrm{i}$ «відповідальність» перебувають в одній площині та мають єдиний критерій виміру - права та свободи людини і громадянина. Разом із тим їх не потрібно ототожнювати. Безпосередньо, поняття «захист» пов’язано з конкретним правопорушенням, а в подальшому притягненням винних до відповідальності. Але заходи захисту також застосовуються і у випадку оспорювання прав. Крім того, метою застосування заходів захисту є не тільки поновлення, а і визнання прав, а також припинення правопорушення. Таким чином, захист являю собою сукупність заходів, спрямованих на відновлення, визнання прав та на припинення порушень прав, які застосовуються компетентним органом самостійно або за зверненням правомочної особи.

\section{Jimepamypa}

1. Конституція України : Закон України від 28.06.1996 р. № 254к/96-ВР. Відомості Верховної Ради України. 1996. № 30. Ст. 141.

2. Рішення Європейського суду з прав людини від 05.04.2005 «Афанасьєв проти України» (заява №38722/02). URL : https://zakon.rada.gov.ua/laws/show/980_239\#Text.

3. Карпа М. Порядок вирішення публічно-правових спорів. Державне управління та місцеве самоврядування. 2017 № 3(34). С. 26-34.

4. Зеленцов А.Б. Функции административной юстиции и их значение для совершенствования государственного управления. Ежегодник публичного права 2015 : Административный процесс. Москва : Инфотропик Медиа, 2015. $464 \mathrm{c.}$

5. Ковалів М.В., Гаврильців М.Т., Стахура І.Б. Адміністративне судочинство : навчальний посібник. Львів : Львівський державний університет внутрішніх справ, 2014. 596 с. html.

6. URL : http://libnet.com/content/10080_Sytnist_sybektivnih_pyblichnih_prav_privatnoi_osobi.

7. Колпаков В.К. Адміністративне право України : підручник. Київ : Юрінком Інтер, 1999. 736 с.

8. Адміністративне право України : підручник. для юрид. вузів і ф-тів / Ю.П. Битяк, В.В. Богуцький, В.М. Гаращук та ін. ; за ред. Ю.П. Битяка. Харків : Право, 2001. 528 с.

9. Державне управління: проблеми адміністративно-правової теорії та практики / за заг. ред. В.Б. Авер'янова. Київ : Факт, 2003. 384 с

10. Бахрах Д. Н. Административное право : учеб. для вузов. Москва, 1996. 355 с.

11. Про звернення громадян : Закон України від 02.10.1996 p. № 393/96-ВР. Відомості Верховної Ради України. 1996. № 47. Ст. 256.

\section{Анотація}

Зуй В. В. Співвідношення понять «захист і охорона суб'сктивних публічних прав» та «відповідальність за порушення суб'єктивного публічного права». - Стаття.

У статті досліджується співвідношення понять «захист суб'єктивних публічних прав» та відповідальність за порушення суб'єктивного публічного права. Автор розглядає ряд нормативно-правових актів, в яких закріплено нормативні основи регулювання захисту суб'єктивних публічних прав. Необхідний елемент цього механізму - адміністративний порядок оскарження та ефективна судова система, здатна задовольнити стандарти верховенства права у сфері захисту прав людини у публічних правовідносинах, що забезпечує можливість оскарження в суді рішень, дій чи бездіяльності суб'єктів владних повноважень. В адміністративному праві під захистом зазвичай розуміють адміністративно-процесуальну функцію як один із напрямків процесуальної діяльності, що складається із дій учасників адміністративного процесу. Звернено увагу на поняття «захист і охорона суб’єктивних публічних прав» та запропоновано класифікації суб'єктивних публічних прав. Варто зазначити, що 
суб'єктивні публічні права захищають не тільки сферу особистих інтересів, а й сферу публічних інтересів (наприклад, захист інтересів держави від незаконних дій платників податків). Варто зазначити, що суб'єктивні публічні права захищають не тільки сферу особистих інтересів, а й сферу публічних інтересів (наприклад, захист інтересів держави від незаконних дій платників податків). Таким чином, можна зробити висновок, що суб'єктивні публічні права спрямовані, з одного боку, на посилення соціальної ролі держави, а з іншого - обмежують публічну владу, забезпечуючи особисті інтереси громадян у публічній сфері.

Здійснений аналіз дає підстави для висновку про те, що поняття «охорона» і «захист» і «відповідальність» перебувають в одній площині та мають єдиний критерій виміру - права та свободи людини і громадянина. Разом із тим їх не потрібно ототожнювати. Насамкінець, у випадках прийняття незаконних рішень, незаконних дій чи бездіяльності органів державної влади, органів місцевого самоврядування, їхніх посадових і службових осіб кожній особі надається право на захист.

Ключові слова: охорона, захист, відповідальність, адміністративно-правові відносини, суб'єктивні права, учасники адміністративних відносин, класифікація суб’єктивних публічних прав.

\section{Summary}

Zui V.V. Correlation of the concepts "protection and preservation of subjective public rights" and "responsibility for violation of subjective public law". - Article.

The article examines the relationship between the concepts of "protection of subjective public rights" and liability for violation of subjective public law. The author considers a number of normative legal acts in which the normative bases of regulation of protection of subjective public rights are fixed. A necessary element of this mechanism is an administrative appeal procedure and an effective judicial system capable of meeting the rule of law in the field of human rights protection in public relations, which provides for the possibility of appealing in court against decisions, actions or omissions of public authorities. In administrative law, protection is usually understood as an administrative-procedural function as one of the areas of procedural activity, consisting of the actions of participants in the administrative process. Attention is paid to the concept of "protection and preservation of subjective public rights" and classifications of subjective public rights are proposed. It should be noted that subjective public rights protect not only the sphere of personal interests, but also the sphere of public interests (for example, protection of the interests of the state from illegal actions of taxpayers). It should be noted that subjective public rights protect not only the sphere of personal interests, but also the sphere of public interests (for example, protection of the interests of the state from illegal actions of taxpayers). Thus, we can conclude that subjective public rights are aimed, on the one hand, at strengthening the social role of the state, and on the other - limit public power, ensuring the personal interests of citizens in the public sphere.

The analysis gives grounds to conclude that the concepts of "protection" and "protection" and "responsibility" are in the same plane and have a single criterion of measurement - the rights and freedoms of man and citizen. However, they do not need to be identified. Finally, in cases of illegal decisions, illegal actions or inaction of public authorities, local governments, their officials and officials, everyone is entitled to protection.

Key words: protection, defense, responsibility, administrative-legal relations, subjective rights, participants of administrative relations, classification of subjective public rights. 